\title{
CONTEMPORARY BIOETHICAL PERSPECTIVES REGARDING THE FAMILY
}

\author{
Ph.D. Florea ŞTEFAN ${ }^{1}$, \\ PhD. Marian PUIESCU', \\ Doctoral School of Theology „1 Decembrie 1918” University of Alba Iulia ${ }^{1}$, \\ Faculty of Theology and Sciences of Education, Valahia University of Târgovişte ${ }^{2}$, \\ ROMANIA \\ Email ${ }^{1}$ : pr_floreastefan@yahoo.com \\ Email2: marian.puiescu@yahoo.com
}

\begin{abstract}
This article presents the problem of the family from the Contemporary bioethical perspectives. The family represents the optimal environment in which man can fulfil himself, the natural path of human becoming. But the familial itinerary is subjected to numerous challenges and temptations, because the contemporary social context is one that minimizes the religious values and choices. Family represents a value and an institution that is necessary to our world and that cannot be replaced by anything else, and from our perspective the most viable familial reality is the traditional one.
\end{abstract}

Keywords: bioethics; family; abortion; contraception; Church; adultery;

\section{INTRODUCTION}

Without God, man seems to have become free, but he is rather free of life, or better said free in death, for he gained the liberty of the desert, arid and senseless (a fact that may be also observed in the progress of the civilization of death, so intensely preached today).

We understand why the world is diagnosed as suffering of lack of spirituality, the hardest and most spread suffering. All there is needed is Jezechiel's vision to come to life and the Spirit, who blows wherever He wishes, would pass again over the great field of the world's words. We will never be able to say how much God is Another, completely other. The danger of the projections is always present for us; to imagine a God who is far away from us, from our experiences and we already have created an idol of our minds. For these words, The One Who is completely Another make of our expectation an incomprehensible alterity, with cannot be measured. We must stress that we are not dealing with the rich and benefic recognition of alterity to which philosophers and psychologists recognize its role in interhuman relations, in love and friendship. It is an alterity for which we cannot have a common measure.

Which significance does it have the relationship with this Other? If he is Other, can he be meat? Can he be close to us? Close to our aspirations? How does He manifest and works in our lives and that of the world? Can He say something about our lives, about morality and family? We, Christians, believe that yes, God rations our life, He is the Spring and Master of life, while our moral decisions affect our life and those around us.

Central institution for the Judeo-Christian space, family represents one of the most respectable institutions of the contemporary Euro-Atlantic space, because it is the traditional bearer of the fundamental values within this geographic and religious space, but also because 
it concentrates a special vision about world and life ${ }^{1}$. Considered pillar and foundation of society and personal development, the most important social construction, icon of Church, „fundamental social human community”, family is truly the main source of stability and morality in every human community, basing itself on the biblical perspective on world and life and having in its center the idea of communion, subsidiarity, solidarity, collaboration and love. In postmodernity, family has suffered numerous changes and it still suffers the ideological attack of many groups, especially of secular-atheistic and anti-Christian nature. If for a Christian family is a bastion of Christian principles, for a secular-atheist it represents a bastion of an ancient vision of life, but the present study does not, nevertheless, consider an analyze of the family from the perspective of its interaction with postmodernity, but from ideological perspective, or from the ideas confrontation between the two visions.

Although we clearly position ourselves on the traditional family's side, we respectfully consider any other perspective on family, even if we don't share those ideas, because of the fact that the freedom of thought is the greatest gift that our Creator has offered us, and the human being was endowed with the ability to choose and to discern as one of the greatest godly gifts. Outside a strong, healthy family we cannot conceive the human community, because the social relations, the fundamental ethical principles and the basic human values are being taught and exercised correctly and thoroughly only within the familial environment.

Family is, therefore, a source of morality for the entire society, a model of human relations and center of strength and stability. Without family there can be no human community or society and history demonstrates us that no human society ever existed without family at its foundation. Further on we will analyze, from the Christian bioethics perspective, from eastern orthodox perspective, some urgent and very important issues for the morality of today's man.

\section{FAMILY'S SPIRITUAL AND BODILY FRUITFULNESS}

One of the most important issues regarding the family, projection of the Holy Trinity within the human society ${ }^{3}$ and the basic cell of the human society ${ }^{4}$ is its fertility. Here we may ask several questions. Is a family without children complete, or not? The problem must be considered from biblical perspective: children are a gift and a blessing from God. In the Judaic and Judeo-Christian antiquity, the absence of children was the sign of a divine punishment, which was the lack of immediate familial fulfillment. We have the example of Zachary and Elisabeth who, until the birth of John, the future Saint, Baptizer and advent prophet, have suffered the vituperation from the part of their community.

But if we are to deepen the essence of this issue, is the purpose of the family the birth of children only?

If we were honest we should see that children are indeed a great gift and a blessing for any family, but there are also cases when for exclusively medical reasons - although in

\footnotetext{
${ }^{1}$ Chipea F., Familia contemporană - tendinţe globale şi configuraţii locale, Bucharest, Expert, 2011

${ }^{2}$ Teoctist, Patriarch, "Mesaj la deschiderea Congresului Internaţional «Familia şi Viaţa la începutul unui nou mileniu creştin»”, in Actele Congresului Internaţional „Familia şi Viaţa la începutul unui nou mileniu creştin, Bucharest, EIBMBOR, 2001; Ciubotea, IPS Daniel, "Familia creştină-Biserica de acasă”, in Familia creştină azi, Iaşi, Trinitas, 1995; Mihaita, IPS Nifon, Misiologie creştină, Bucharest, Asa, 2005

${ }^{3}$ Popescu D., "Famila în cultura secularizată”, in Actele Congresului Internaţional „Familia şi Viaţa la începutul unui nou mileniu creştin”, Bucharest, EIBMBOR, 2001

${ }^{4}$ Gherghel P., Familia creştină şi căsătoria. In DT; 8/2001
} 
this point we might juggle with the terms, because in the eastern tradition there is also the idea that the impossibility of having children is caused by a sin - a family cannot have descendants. It is nevertheless a family, although the immediate temptation is to consider it unfulfilled. Still, we shouldn't regard things through these lenses.

The family's main purpose is the manifestation of love between the two husbands, man and woman, the mutual relieving, the cooperation between them, the spiritual development of the two and the increasing communion, the personal becoming, because the main eschatological purpose of each one is redemption. Thus, each of the two husbands becomes a redemption ladder for the other. The main purpose is, therefore, a deepening of the communion, a mutual spiritual evolution, a fact which doesn't exclude fertility, viewed from spiritual perspective ${ }^{5}$. Family is based on love as purpose and main objective, because God who is Trinity of Persons and One in Being, is a model of perfection, of familial love, $\mathrm{He}$ "institutes existence and life as an event of love and personal communion". Same as the Trinity's persons are connected to one another by a perfect love (God, in His essence, is love!) discovering one another and being oriented towards one another.

In this way, although they cannot have any descendants, the two may fathom the relation of communion between them and support their spiritual development, which is the most important fact. At this level, from this perspective, we notice that we may speak of an extremely important spiritual and cultural paternity or maternity, because the godly demand is "be fruitful and increase in number", not only "increase in number", and this increase means spiritual and cultural fathoming (Genesis 1, 26). Human kind has known many geniuses, either they were unmarried, either married men with no children, which doesn't mean that they were less important for the history of humanity.

Considering the couples who wish, but cannot have children, regarding from bioethical perspective we are dealing with the technical medical issue about the possibility of making children. Here we should discuss the practice of artificial insemination, or in vitro. The problem is simple. In order to have higher chances of success, several fecundated ovules are implanted in the female's uterus, but the problem appears when most of them die or appears the possibility of multiple carriages and the parents chose to allow the evolution of only one of them.

From moral point of view, we have the following problem: is it correct to manipulate life in such a manner? To choose which embryo to live and which one to die? Aren't we taking the Creator's place? Of course, we are responsible with protecting life and not allowing death to make us its instruments. It is moral to do everything it takes to have offspring, but without affecting the life which manifests itself and without putting an end to the right to life of any other potential embryo ${ }^{7}$. Here it must be stressed that any practice which leads to the destruction of life, of a future embryo with potentiality of life is completely immoral and a faithful man should regard the problem in this manner. Then, if this is the only medical solution, we must ask ourselves whether adopting a child isn't a more natural act than pushing the limits of human nature and destroying life and the potentiality of life.

We are also dealing with the problem of "substitute mothers" - if in a couple the woman cannot have children, from medical causes, then either on artificial or natural ways,

\footnotetext{
${ }^{5}$ Baconski Theodor, Iacob şi îngerul. Bucharest: Humanitas; 1997

${ }^{6}$ Yannaras Christos, Libertatea Moralei. Bucharest: Anastasia; 2002

${ }^{7}$ Evdochimov P., Taina iubirii, Bucharest, Christiana, 1994
} 
the husband can fecundate a woman who is willing to carry the child of that couple. In this situation, the problem is immoral from the very beginning.

Either we are referring to the procreation act outside marriage, either we are talking about the fact that the artificially fecundated ovule of a couple is implanted to a substitute mother, it is immoral, because the child creates a special bond with the mother and a mother cannot be only a carrier, being actually an intromission of a foreign person within the couple, which is a form of adultery, be it partial or virtual, which creates a serious moral problem ${ }^{8}$.

\section{THE ETHICS OF FAMILY'S FERTILITY}

Another issue that might appear in connection with the family, „basic cell at the foundation of the social organism" and terrestrial image of Trinity ${ }^{9}$, is about the medical means that stimulate fertility. These may morally be used, if they do not affect the corporal or spiritual health of the person who uses them. The condition is thus not to affect the user's health $^{10}$.

Nowadays, there is also the challenge of experiencing new fertilization treatments which, from moral perspective, raise the same problem, that of affecting the health of the person who uses these medical or medicamentary practices. Thus, if these experiments does not affect, limit or deform life and human health, then they are entirely moral and good to use. Corelative to this problem it is also the use of contraceptives or other contraceptive techniques which give their users the illusion of the liberty of deciding when to conceive a child. They forget that the latter is God's ineffable gift and he who cannot have children would better adopt. Then, the purpose of marriage is to fulfill love, the mutual aiding, walking on the path to fulfillment and the procreation of children, as main purpose, but not the only purpose ${ }^{11}$.

Because they stop, effectively or virtually, the possibility to conceive and they serve the culture of death, of individuality and of pleasure, because it is medically proved that they affect the quality of human life and are foreign of promoting, respecting and supporting life, contraceptives are considered immoral. It is true that many people who believe themselves faithful accept them, considering that they have the right to conceive when they decide, which is why they use them deceiving their conscience that they avoid a greater evil, abortion or abandoning the newborn. But morally speaking the problem is wrongly approached, because the Christian leads himself according to the Holy Scripture, and in some confessional traditions the Holy Tradition has the same normative value. According to the latter, because they stand against life and our Creator, the contraceptive means raise serious moral problems.

The only accepted method for limiting the number of children is either restraining, either the so-called method of the biologic calendar, based on the increasing or the decreasing of the woman's basal temperature during the fertile periods or, inversely, the infertile ones.

\footnotetext{
${ }^{8}$ Mihoc C., Taina Căsătoriei şi familia creştină în învăţăturile Sfinţilor Părinţi din sec. al IV-lea, Sibiu, Teofania; 2002

${ }^{9}$ Sârbu C., Familia în cadrul învăţăturii creştine. In Mitropolia Moldovei şi Sucevei; 3-4/1968; Mladin N., Studii de Teologie Morală. Sibiu: Ed. Tipografiei şi Arhiepiscopiei; 1969

${ }^{10}$ Remete G., "Familia şi planningul familial", in Actele Congresului Internaţional "Familia şi Viaţa la inceputul unui nou mileniu creştin”, Bucharest: EIBMBOR; 2001

${ }^{11}$ Moldovan I., Adevărul şi frumuseţea căsătoriei. Alba Iulia; 1996
} 
Sexuality is not considered something evil and immoral and the birth of children is an auxiliary objective to marriage but, nevertheless, the morality of these connections is important, for life is bound to them, like the birth on new men in this world and the transmission of life. For this reason, sexuality, as key of life, and physical means of appearing into this world, has a predominant importance and cannot be simply exposed to pleasure, to human vices and caprices ${ }^{12}$.

Family is the unique appropriate environment in which a child can come into this world, the only favorable environment for the fulfillment of love ${ }^{13}$ being, from the perspective of Christian moral, the only optimal environment for the development, carrying and the appearance of human being.

In the family, both the father and the mother have an important role in the child's healthy and harmonious raising, each of them contributing to the genetical, spiritual and cultural dower of the newborn. Even emotionally, the appearance of a child outside the marriage or him being raised by only one parent represents an unhappy, abnormal and problematic situation for the child's harmonious, normal and natural development.

Choosing to have a descendant is a responsible decision and a manifestation of human liberty, but it doesn't represent everything because He Who is the Spring of life has, in this matter, the most important decision. Thus, sometimes there is at least apparently the possibility of giving birth to a child in the couple, but it fails to appear, other times the reproductive health of one of the members of the couple is irremediably affected, but the child nevertheless appears. It is also possible for a child to appear even if contraceptive methods are being used in the couple, without even being affected by them. This fact shows us that God is the One who has the final word concerning the appearing of life, and man is only the secondary operator of this life's mise en scene.

The conclusion is that everything that opposes to life, it limits and affects it cannot be moral and a good Christian will avoid this. The key or the deciphering code for these bioethics issues is this: man must stand in the service of life, of the culture of love, and never the other way around ${ }^{14}$. The responsibility to God's image which exists in each of us, to the magnificent gift of life consists in the respect towards life in all its stages and forms as a reflection of the Creator's will, the only one who is the Master of life and death, the absolute Lord of our existence ${ }^{15}$.

\section{DIVORCE - WOUND OF THE FAMILY AND VIOLATION OF GOD'S WILL}

Another major issue in the contemporary bioethics is connected to divorce, namely the separation of the two husbands and the breaking of the marriage bond. Christianity respects almost completely the biblical principle that what God had bonded, man cannot break, which is why the indissolubility of marriage is regarded as godly will.

For the human frailness, there is nevertheless the possibility of remaking marriage and the allowance to let the man marry three times at the most in the orthodox Church, while the Catholic one doesn't accept divorce in any form ${ }^{16}$. Divorce is breaking the bond of love, or in other words its concrete aspect of alienation and separation. Even if in certain religious

\footnotetext{
${ }^{12}$ Rose S, Un singur trup, amândoi o singură fiinţă. Bucharest: Sofia; 1997

${ }^{13}$ Mayendorff J., La marriage dans le perspective orthodoxe. YMCA Press; 1986

${ }^{14}$ Breck J., Darul sacru al vieţii. Tratat de bioetică. Cluj-Napoca: Patmos; 2003

${ }^{15}$ Ilioaie Ş., Cultura vieţii-aspecte morale în bioetică. Cluj-Napoca: Renasterea; 2009

${ }^{16}$ Trifa G I., "Violența domestică și divorțul - provocări majore pentru Biserică și Școală", in Educația din perspectiva valorilor, VIII ${ }^{\text {th }}$ ed. Bucharest: Eikon
} 
traditions man is allowed a second and a third marriage, this allowance is a sign of understanding the human flaws and not a habit or a state of normality. Separating yourself from the man you united with before God represents His dishonoring and a breaking of your own promise of fidelity and the marital commitment. Marriage involves offering, abnegation, sacrifice, which is why divorce is unacceptable, for it means dishonoring the charisma, the refusal of surpassing the challenges together.

In the space of the Old Testament, divorce was allowed only for adultery, the only viable reason in Christianity also, perhaps because deceiving of one of the husbands breaks the marriage's indissolubility. In the Christian space, the approach is quite different, but most theologians speak about divorce as being an abnormality, a sin. This is why in the Orthodox space the second or the third marriage is considered only a special prayer and not a Sacrament and is granted only after a period of penitence.

Unfortunately, in the contemporary world divorce is considered a privilege of man, normality within the community, while the reasons for divorce have multiplied, in eager rivalry hilarious or superficial. Divorce is often caused by the fact that those who wish to marry do not put at the base of their relationship a common vision about world and life, but the pleasure, the interest or the ego. From Orthodox Christian perspective, divorce is unacceptable because it manifests superficiality towards the commitments taken before God and the significant half. The main cause of divorce is a superficial perspective about life and putting the relation of marriage on unsolid, emotional or superficial base. What should prevail in choosing a partner is, first of all, the existence of common moral and religious principles, of a compatible vision about the community and the will to remain faithful next to one another. The lack of a systematic and profound catechesis makes the majority of faithful Christians smaller and smaller. Those who consider themselves faithful, but break fundamental religious rules, are in a huge moral problem regarding their faith. Considering the Christian values as being negotiable and with no absolute normative value, even indirectly, for most Christians are unaware of that, lead to the marriage's failure in divorce ${ }^{17}$. Divorcing, breaking yourself from the unity of marriage is a wound on the Church's body, on the community in which the family lives, but also a missionary, educational and moral failure of the Church which was not able to intervene in this case in a beneficial and efficacious manner.

\section{ABORTION-CRIME AGAINST HUMANITY AND ANTI-FAMILIAL AND IMMORAL ACT}

Abortion represents a reality of the world we live in, either we are referring to faithful or non-believers. It represents, for the one who believes, an interruption of the life of a becoming human being. In their large majority, the Christian believers consider that human life appears as godly gift from the moment of the conception, which is why any intervention whatsoever upon the future grown human being is considered a crime.

Thus was considered abortion by Christians in all times and places, because putting a stop to a life is considered overtaking human prerogatives, because man has no right to take a life, either to a born or unborn human being. "Human being remains a human being no matter the dimensions it has and the environment where he lives. Wherever there is a

\footnotetext{
${ }^{17}$ Balswich J O., Balswich J. K., Familia, o perspectivă creştină asupra căminului contemporan, Oradea: Casa Cărţii; 2009
} 
stopping of this evolution, we are dealing with murder $^{18}$. From bioethics perspective, the problem is this: can we really speak about human life from the conception? Some say that human is only the born being, others that the moment of life is not at all at the conception.

From theological perspective, we are guiding ourselves after the immutable godly Revelation, which asserts the existence of life, of person, from the moment of conception. From human perspective, we are guiding ourselves after the results obtained by science, which also shows that life appears from the moment of conception, as manifestation, as biofield and behavior inside the mother's body.

The human being is the most important for the Creator, for it is for man that God chose to come into this world, to become a man, which is why man has a huge value, greater than the one of the universe as a whole, for he is a reflection of God's image. This is why, no matter her age, the human being has the right to existence, which only God can give or take $^{19}$. Unfortunately, we see that abortion appears especially at young people, who are not married and have occasional sexual relations, outside family, and abortion is a solution to the fact that in their life had appeared a child whom they do not want. The main cause is the precarious education, the lack of adequate catechesis and the lack of a religious sense of life.

It is immoral to take a life which you cannot give; it is immoral to interrupt a life only because you didn't know how to restrain yourself or to avoid having offspring you didn't want ${ }^{20}$. The Christian bioethics consider abortion as being the greatest moral evil for a mother, because abortion has poisonous psychical consequences, the feeling of guilt terrorizing the life of the one who chose this inhuman and immoral solution. Therefore abortion raises the problem of the right to decide whether to let continue or to stop the life of another, all the more so given the conditions that for a faithful man the human being is a person ever since the conception.

Why do we consider that life appears in the moment of conception? Because after that in unfolds naturally according to some observable stages that culminate at birth. We consider that, even if in is unborn yet, the human being has the right to life, because we are speaking about a human being and we do not have the right to alter the exclusive privilege of the Creator to give and take life to man. We must underline the fact that giving life or taking life to humans is an exclusive right of God. Man is called by God to life and without Him and His will there can be no life. Therefore, the right to existence is a godly gift which cannot be undertaken by man in any form whatsoever.

\section{EXPERIMENTS ON MAN AND PALLIATIVE PRACTICES}

The consent regarding human experiments or putting a stop to a life is, in Christian perspective, connected to family life as a whole. When man agrees to be a part of a medical experiment, he has to embrace as exegetical key not only his interest, but also his family's good. This is why he will accept to take this risk only after the family agrees, and the experiment's results may be useful to humanity itself. The members of the family must know that they are responsible for each other, that they have the duty to sustain and aid themselves, and any decision affecting in any measure their family they wish to take, has to be taken in

\footnotetext{
${ }^{18}$ Pop I., Contracepţia din perspectivă ortodoxă, Babeş-Bolyai Publishging, 2007. URL: https://www.ceeol.com/search/article-detail?id=254812

${ }^{19}$ Moldovan I., Iubirea taina căsătoriei.Teologia iubirii, Vol. I., Alba-Iulia: Tipografia Episcopiei Ortodoxe; 1996

${ }^{20}$ Ionascu, Pr. Juvenalie, Teroriştii uterului. Terorism ştiinţific şi etica începuturilor vieţii, Eseu de bioetică a gestaţiei, Bucharest, Anastasia, 2002
} 
consensus with the family and considering its interests. We have to exclude, here, the experiments based on financial gain or on other personal interests ${ }^{21}$. In the same optic we have to consider also the problematics of transplant, which is good and useful ${ }^{22}$, but the decision to give an organ to the benefit of another must not affect the familial life, or to be a source of financial gain, but to serve the love for those close to us ${ }^{23}$. The Church blesses any medical practice which has the purpose of reducing sufferance in the world, therefore also the transplant made with respect for the receiver and the donner, live or dead.

A problem that is often encountered, collateral to our problematics, is the one in which members of the family are in a terminal stage of the illness, and the others have to make a decision about using medicines that ease suffering, but reduce life, or about other palliative medical practices ${ }^{24}$. A moral problem that appears here is this: is it moral to decide to shorten the life of a relative, by using medicines that diminish sufferance, or do we let her suffer, sometimes agonizingly, to the natural end of her life ${ }^{25}$

The issue is not at all simple or easy, and the interpretation key is this: we have to protect human life, but not with the price of human suffering, unless the one who suffers haven't decided otherwise. This moral affirmation must consider not the easiness of life and the avoidance of suffering by all means, but to avoid the maximum of suffering, because otherwise it justifies even if indirectly euthanasia, and the Church follows the principle that life is God's gift and only He can take it away, while man has no right whatsoever to do this.

The family has no right of life and death upon any of its members, but it has the responsibility to protect the life of the members and, as much as possible, in extreme conditions, to avoid the maximum of pain and suffering ${ }^{26}$.

Familial morality is a break against sin and a means to protect the sacramental fidelity of this holy sacrament. To live morally is not an option of will, but a necessity of life, in order to make life on earth bearable and to give man the chance to change and to evolve towards the discovery of his own existential purpose.

To live morally within family is to respect a way of life according to what the Creator wanted for us, because only in this way will we have the potential guarantee of fulfilling the purpose of our lives and avoiding failure.

\section{CONCLUSIONS}

As we have seen, the family represents the optimal environment in which man can fulfil himself, the natural path of human becoming. But the familial itinerary is subjected to numerous challenges and temptations, because the contemporary social context is one that minimizes the religious values and choices.

Family represents a value and an institution that is necessary to our world and that cannot be replaced by anything else, and from our perspective the most viable familial reality is the traditional one. Considering that God has created man after His image, it becomes obvious that fulfillment has to do with the man's need to follow a model, otherwise

\footnotetext{
${ }^{21}$ Scripcaru G, Ciuca A, Scripcaru C, Bioetica, stiintele vietii si drepturile omului. Iaşi: Polirom; 1998

${ }^{22}$ Andronikof M., "Un punct de vedere ortodox asupra transplanturilor de organe", in Revista Teologică, 8 , $1 / 1998$

${ }^{23}$ Sgreccia E, Tambone V., Manual de Bioeticã, Bucharest: Editura Arhiepiscopiei Romano-Catolice de București; 2001

${ }^{24}$ Engelhardt Jr. H. Tristram, Fundamentele bioeticii creştine. Perspectiva ortodoxă, Sibiu: Deisis; 2005

${ }^{25}$ Stan G., Teologie si Bioetica, Alexandria: Biserica Ortodoxă; 2001

${ }^{26}$ Bogdan C., Eutanasia şi suicidul asistat medical, din nou în actualitatea dezbaterii international, in Revista Română de Bioetică , 1/2004
} 
our life, in all her forms of daily, religious, professional, familiar existence, would suffer a huge vacuum if we would not have points of reference, in other words models of life with parable value, which to motivate our facts, thought and will, giving us the courage to engage ourselves in difficult moments and the strength to become better than we were when life asks it of us. The interpretation key of the moral actions, from Christian perspective, regarding human existence, is protecting and sustaining life in any situation but as God's exceptional, ineffable, full of love, gift. It is from this perspective that we must understand the problematics of families with or without children, of the transplant of organs, of experiments on humans, of abortion, divorce or the palliative practices we have talked about.

Whatever puts a stop to life, deforms the existential reality, affects or aggresses human life is abnormal and immoral and, therefore, is of no use to man. Christianity does not absolutize suffering, it does not believe in its necessity, but believes in its conscious and responsible bearing and its surpassing with the aid of the godly charisma.

Among all the challenges our world has to face, those that affect familial life can be considered aggressions against life, have an immoral character and are unprofitable for the life of the community. In conclusion, all that promotes life is moral, while promoting life represents a duty and an obligation for any human being that exists from the Creator's will.

\section{BIBLIOGRAPHY:}

[1] Andronikof M., "Un punct de vedere ortodox asupra transplanturilor de organe", in Revista Teologică, $8,1 / 1998$.

[2] Baconski Theodor, Iacob şi îngerul. Bucharest: Humanitas; 1997.

[3] Balswich J O., Balswich J. K., Familia, o perspectivă creştină asupra căminului contemporan, Oradea: Casa Cărţii; 2009.

[4] Bogdan C., Eutanasia şi suicidul asistat medical, din nou în actualitatea dezbaterii international, in Revista Română de Bioetică, 1/2004.

[5] Breck J., Darul sacru al vieții. Tratat de bioetică. Cluj-Napoca: Patmos; 2003.

[6] Buta M. Gelu editor, Medicii şi Biserica, vol. 6: Perspectiva ortodoxă contemporană asupra sfârşitului vieţii, Cluj-Napoca: Renasterea; 2008.

[7] Chipea F., Familia contemporană - tendinţe globale şi configuraţii locale, Bucharest, Expert, 2011.

[8] Ciubotea, IPS Daniel, "Familia creştină-Biserica de acasă", in Familia creştină azi, Iaşi, Trinitas, 1995.

[9] Engelhardt Jr. H. Tristram, Fundamentele bioeticii creştine. Perspectiva ortodoxă, Sibiu: Deisis; 2005.

[10]Evdochimov P., Taina iubirii, Bucharest, Christiana, 1994.

[11] Gherghel P., Familia creştină şi căsătoria. In DT; 8/2001.

[12]Ilioaie Ş., Cultura vieţii-aspecte morale în bioetică. Cluj-Napoca: Renasterea; 2009.

[13] Ionascu, Pr. Juvenalie, Teroriştii uterului. Terorism ştiinţific şi etica începuturilor vieţii, Eseu de bioetică a gestaţiei, Bucharest, Anastasia, 2002.

[14] Mayendorff J., La marriage dans le perspective orthodoxe. YMCA Press; 1986.

[15] Mihaita, IPS Nifon, Misiologie creştină, Bucharest, Asa, 2005.

[16] Mihoc C., Taina Căsătoriei şi familia creştină în învăţăturile Sfinţilor Părinţi din sec. al IV-lea, Sibiu, Teofania; 2002.

[17] Mladin N., Studii de Teologie Morală. Sibiu: Ed. Tipografiei şi Arhiepiscopiei; 1969.

[18] Moldovan I., Adevărul şi frumuseţea căsătoriei. Alba Iulia; 1996.

[19] Moldovan I., Iubirea taina căsătoriei.Teologia iubirii, Vol. I., Alba-Iulia: Tipografia Episcopiei Ortodoxe; 1996.

[20]Pop I., Contracepţia din perspectivă ortodoxă, Babeş-Bolyai Publishging, 2007. URL: https://www.ceeol.com/search/article-detail?id=254812

[21] Popescu D., "Famila în cultura secularizată”, in Actele Congresului Internaţional „Familia şi Viaţa la începutul unui nou mileniu creştin”, Bucharest, EIBMBOR, 2001. 
[22] Remete G., "Familia şi planningul familial", in Actele Congresului Internaţional "Familia şi Viaţa la inceputul unui nou mileniu creştin”, Bucharest: EIBMBOR; 2001.

[23] Rose S, Un singur trup, amândoi o singură fiinţă. Bucharest: Sofia; 1997.

[24] Sârbu C., Familia în cadrul învăţăturii creştine. In Mitropolia Moldovei şi Sucevei; 3-4/1968.

[25] Scripcaru G, Ciuca A, Scripcaru C, Bioetica, stiintele vietii si drepturile omului. Iaşi: Polirom; 1998.

[26] Sgreccia E, Tambone V., Manual de Bioeticã, Bucharest: Editura Arhiepiscopiei Romano-Catolice de București; 2001.

[27] Stan G., Teologie si Bioetica, Alexandria: Biserica Ortodoxă; 2001.

[28] Teoctist, Patriarch, "Mesaj la deschiderea Congresului Internaţional «Familia şi Viaţa la începutul unui nou mileniu creştin»”, in Actele Congresului Internaţional „Familia şi Viaţa la începutul unui nou mileniu creştin, Bucharest, EIBMBOR, 2001.

[29] Trifa G I., "Violența domestică și divorțul - provocări majore pentru Biserică și Școală”, in Educația din perspectiva valorilor, VIII ${ }^{\text {th }}$ ed. Bucharest: Eikon.

[30] Yannaras Christos, Libertatea Moralei. Bucharest: Anastasia; 2002. 